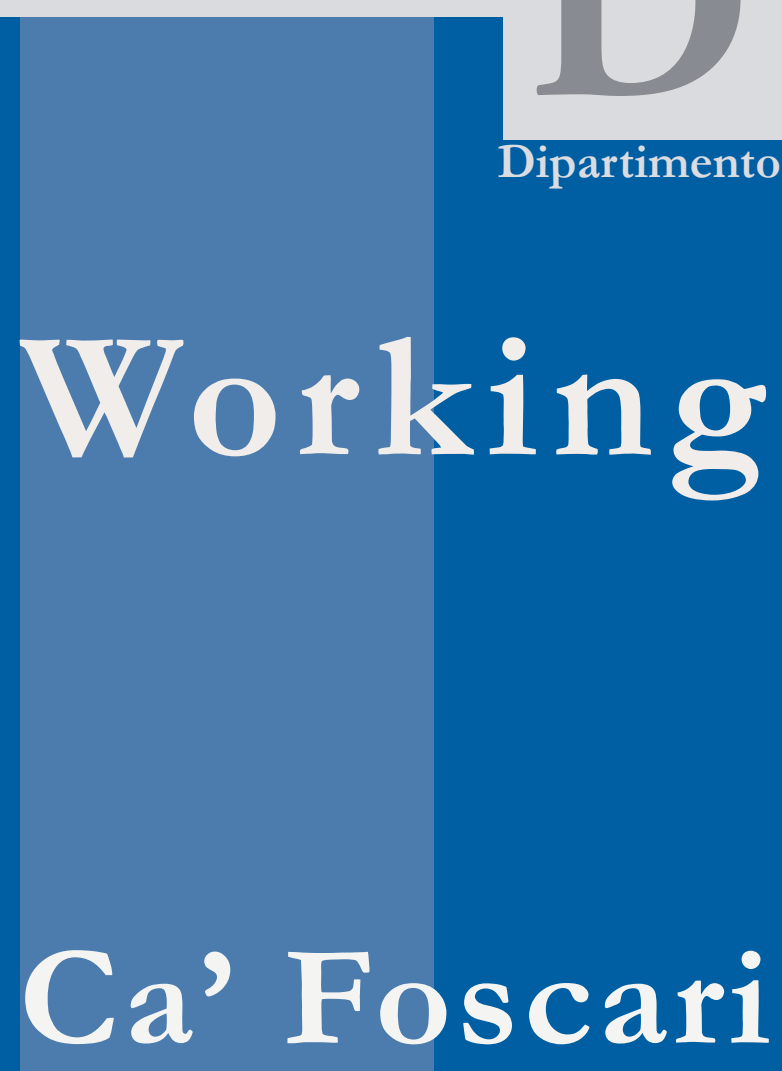

Paper

Department

of Economics

University of

Venice

John Ryan

United Kingdom Euro

Scenarios Assessed 


\title{
United Kingdom Euro Scenarios Assessed
}

\section{John Ryan}

Hult International Business School and CEPA

First Draft: April 2009

\begin{abstract}
After 10 years of abstinence from the European Monetary Union, should the UK be seriously thinking about joining the Eurozone? Especially in view of the European Central Bank's improved reputation as a crisis manager in the wake of the financial crisis, could EMU represent a safe haven for the UK economy? Would it be wise for Britain to attach itself to the reserve currency Euro to avoid the perils of drifting alone on a storm-tossed open sea? These are big questions. They have been debated in the $\mathrm{UK}$ for a generation and have become relevant again during the current financial and economic crises. I will in this short paper assess three scenarios regarding the UK and the Euro - UK entry, EMU collapses before a UK entry, No UK entry and I will discuss the Eurozone view on UK membership.
\end{abstract}

\section{Keywords}

UK Economy, Eurozone, Euro, Sterling, European Central Bank

\section{JEL Codes}

E12, E41, E52, E60, F02

Address for correspondence:

$$
\begin{array}{r}
\text { John Ryan } \\
\text { Flat 7, } 307 \text { Upper Richmond Road, } \\
\text { London SW15 6SS } \\
\text { England } \\
\text { Phone: (++44) } 7951765549 \\
\text { jmtryan@aol.com }
\end{array}
$$

This Working Paper is published under the auspices of the Department of Economics of the Ca' Foscari University of Venice. Opinions expressed herein are those of the authors and not those of the Department. The Working Paper series is designed to divulge preliminary or incomplete work, circulated to favour discussion and comments. Citation of this paper should consider its provisional character.

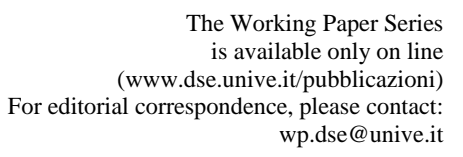

The Working Paper Series

ence, please contact:

Department of Economics

Ca' Foscari University of Venice

Cannaregio 873, Fondamenta San Giobbe

30121 Venice Italy

Fax: ++39 0412349210 
"A weak currency reflects a weak economy and a weak government".

Gordon Brown in the wake of the ERM debacle of 1992

\section{UK Euro Scenarios Assessed}

A UK entry of the Euro would be a difficult operation; many practical steps would need to be resolved and an entry plan developed that would need to be implemented over a number of years.

- While the national policymakers and politicians of all parties remain divided on the issue, the Government's intentions with respect to UK membership of the EMU, and industry's reactions to them, have been discussed in the press extensively over the last ten years.

- If at the same point an entry decision was taken, the date and timing of UK entry would have to be resolved by publication of a new National Changeover Plan.

- The next big uncertainty would be around the timing of a national referendum. The outcome of the referendum cannot be predicted with confidence and therefore UK entry would not be certain even following publication of a proposed entry date by the Government.

Taking this highly complex situation into account, I believe the probability of a UK entry by 2014 is a possibility. However, the uncertainty that would continue to exist throughout a significant period of entry preparation, would add a great deal to the complexity of UK businesses preparing to join the Euro.

The following scenarios are described in the remainder of this paper:

- UK entry

- EMU collapses before a UK entry

- No UK entry 


\section{UK Entry}

Are Italy, Spain and other countries, as they are struggling with high wage costs and low productivity, eyeing Britain enviously, as its currency slumps and its relative wage costs fall with it? Or is Britain wishing it were, like Italy, Ireland and Greece safe inside the Eurozone? Britain has been harder hit by the credit crunch than most Eurozone countries: it had a huge housing boom that is turning to bust; it has a large financial sector, which has seen its financial strength, reputation and brand severely damaged and which is now shrinking fast; and its households are more indebted than even the U.S.

Despite being outside the Eurozone, the City has managed to remain the Eurozone's financial centre over the last decade. The City of London and the UK government should not take this situation for granted. The UK's macroeconomic policy framework may simply not survive this crisis. There must now be a risk of a real sterling crisis at some point.

If the UK had decided to join the Euro well ahead of this current crisis's, the government would have been obliged to run a much tighter fiscal policy, and to take action to cool an overheated housing market. The boom would have been moderated, and so too would have been the bust.

Britain has had stronger growth than some (not all) Eurozone economies. It also faces a deeper recession than most. Prime Minister Gordon Brown, one supposes, will now drop the lectures to fellow Europeans on the virtues of unfettered financial innovation. The global crisis has exposed the delusion that Britain's liberal financial capitalism was inherently superior to the social market model favoured by its Eurozone neighbours. Over time, this will change the terms of Britain's Euro debate.

UK membership in the Eurozone is dictated both by the conventional optimal currency area criteria (convergence, flexibility, labour mobility, fiscal flexibility) and by a new financial stability criterion: without Eurozone membership, the UK is more vulnerable to a triple 
financial crisis - a banking, currency and sovereign debt crisis - because it belongs to a group of countries characterised by the inconsistent quartet: (1) a medium country with (2) a large internationally exposed banking sector, (3) a currency that is not a global reserve currency and (4) limited fiscal capacity relative to the possible size of the banking sector solvency gap.

The case for waiting any longer with a UK application for Eurozone membership has been fatally undermined by the financial crisis that threatens to inflict lasting damage on the UK economy. It would be wise for the UK government policymakers to consider having a contingency plan regarding Euro membership. The graph below outlines the process that the UK would have to address to become a member of the Eurozone.

\section{Euro Timetable}

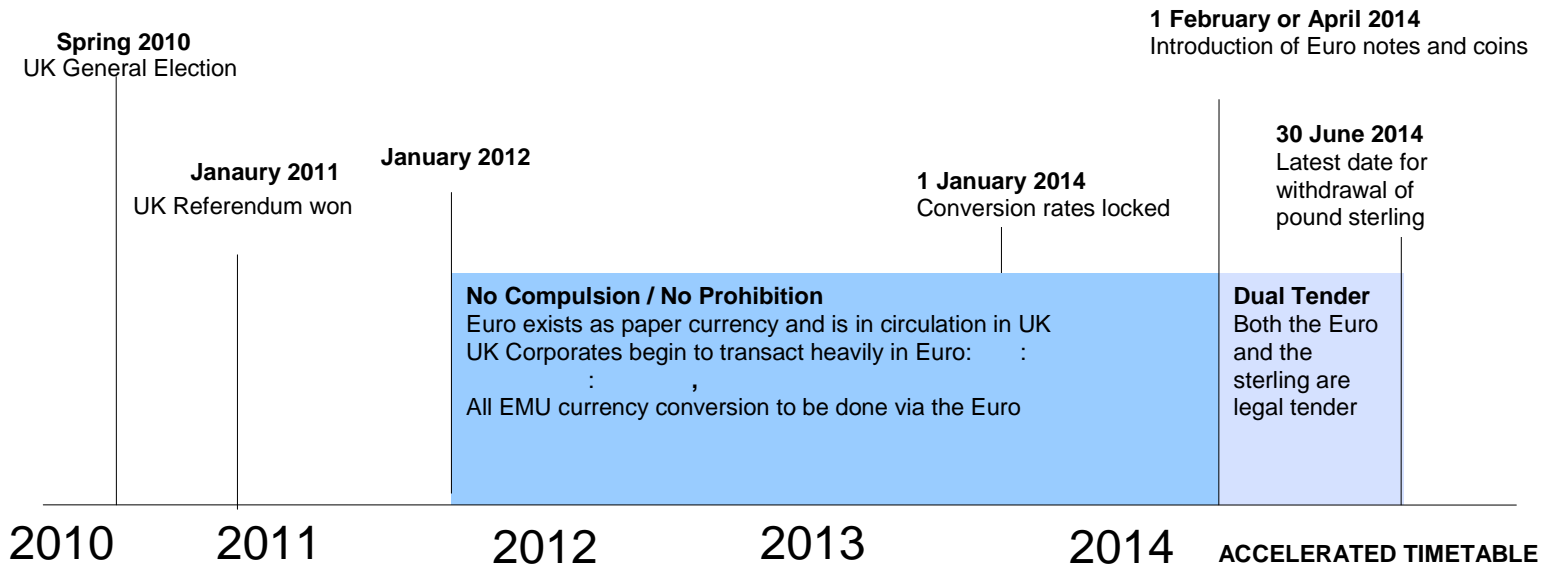

As economic events over the past year have demonstrated, nothing can be ruled out or predicted. But, for the moment, serious debate on the issue of British membership of the Euro remains premature. The UK Government is playing safe by declaring that the policy hasn't changed and that they will focus on other economic issues first. It is too early to tell 
whether the decline of sterling will continue along with that of the British economy. It is clear that the recession will both hit the British and the Eurozone economies. If the UK economy does come out of the economic crisis worse off, then surely Britain should seriously start to consider membership - and therefore scenario planning would need to start soon. With the outcome of the current crisis uncertain I do not think it wise to do nothing on the basis that a possible UK entry scenario may be 15 years away. ${ }^{1}$

\section{EMU collapses before a UK entry}

The break-up of the Eurozone would lead to an economic situation that could put considerable strains on the political commitment of several countries to EMU. Italy is perhaps the most likely candidate for eventual exit, despite the costs involved in so doing, followed by the Netherlands and perhaps then even Germany. Of course, if Germany were to leave then the whole system would effectively become defunct.

Since the Euro was launched in 1999, there have been many mainly U.S. and UK policymaker's who have argued that it would eventually break-up and to this day they have been proven wrong. Germany has acknowledged bail-outs may be needed, suggesting a collapse is a genuine possibility. The only surprise is that it's taken so long for the politicians to face up to economic reality.

Some have rushed to predict the demise of the Euro, but the difference between the performance of the southern and northern European economies has been exaggerated by for example, Simon Tilford of the Centre for European Reform. He predicts that Europe's single currency, which currently includes 16 EU countries, could break up under the strain².

So what would a Eurozone crisis look like? It would have three elements - financial, economic and political. The financial part would come when some of the weaker

\footnotetext{
${ }^{1}$ David Marsh, The Euro: The Politics of the New Global Currency, Yale University Press, 2009 p259

2 Simon Tilford, in “The Euro at Ten: Is Its Future Secure?” Centre for European Reform, January 2009
} 
economies in the Eurozone found the markets were increasingly unwilling to finance their budget deficits. When euro-watchers hyperventilate over the "widening of spreads", this is what they are referring to - the fact that investors are increasingly demanding a higher rate of interest to buy Greek or Italian debt, as compared with debt from the more fiscally disciplined Germans ${ }^{3}$.

The crisis in the real economy would involve all the usual malign elements - recession, unemployment, bankruptcy. But there would also be a direct link to the financial problem. As the markets demanded higher interest rates countries such as Italy, Greece, Spain, Portugal and Ireland would find managing their public finances ever harder. Mr. Tilford notes: "Membership of the euro insulates countries from the risk of a currency crisis, but currency risk can be replaced by credit risk."

Rating agency Moody's, issued a report in response to questions from investors about the threat of a break-up of the Euro. It came down firmly against it. "The risk of a break-up of the European Monetary Union is extremely low as exiting the Eurozone during the current turbulent crisis would have extremely severe financial, economic and political consequences," its report said. ${ }^{5}$ The report, by Arnaud Mares, a senior vice-president at Moody's, identified four reasons why the Euro would not break up ${ }^{6}$

- The ECB already has low interest rates so the potential lower ones outside do not exist; - Countries that leave would suffer the penalty of higher long-term interest rates; - The Euro has offered protection from speculators to smaller economies; - There is no mechanism for countries to leave.

"Adopting the euro is simple, whereas withdrawing from it would be extremely complex and likely to result in severely negative consequences, the magnitude of which would deter any government from contemplating such a policy option”. ${ }^{7}$

\footnotetext{
${ }^{3}$ David Marsh, The Euro: The Politics of the New Global Currency, Yale University Press, 2009 pp254-55

${ }^{4}$ Simon Tilford, in “The Euro at Ten: Is Its Future Secure?” Centre for European Reform, January 2009

${ }^{5}$ Impact of Global Crisis on EMU: Risk of 'Eurozone' Break-Up Negligible, Moody’s, 2009

${ }^{6}$ Impact of Global Crisis on EMU: Risk of 'Eurozone' Break-Up Negligible, Moody’s, 2009

${ }^{7}$ Impact of Global Crisis on EMU: Risk of 'Eurozone' Break-Up Negligible, Moody’s, 2009
} 
Even if the Euro survives the present crisis, the strains will not go away. Economists Wolfgang Münchau \& Susanne Mundschenk outline Eight Scenarios that may occur that would lead to the Eurozone break-up in the future. They state that they believe that most of these scenarios are not plausible. The Eurozone has been more persistent than some of its critics maintain. But it is not invulnerable. ${ }^{8}$

\section{No UK entry}

It is a common view among Eurosceptics that since the UK left the Exchange Rate Mechanism in 1992 we have had on the whole a positive period for the UK economy, because Britain has benefited from flexibility of exchange and interest rates. Their argument is that if Britain had joined the Euro when it started in 1999, interest rates in the UK would have been lower than they actually have been, and hence the credit-fuelled housing and spending boom - and the eventual correction - would have been even worse than they have turned out to be.

The Eurosceptic argument posits that unlike the members of EMU, Britain has the capability to align its monetary policies with its own economic position, and this should prove a benefit in the coming 18 months to two year period of painful adjustment. However, the performance of the UK government, Bank of England and Financial Services Authority leaves a lot to be desired during the crisis.

In Britain Eurosceptics have been dusting off old headlines about the break-up of the single currency, after the gap widened dramatically in recent weeks between Germany's bond yields and what Portugal, Italy, Ireland Greece and Spain - referred to as the PIIGS countries - were offering on government debt. The market signals seemed to be saying that Italy, Spain, Ireland and Greece cannot be trusted to share a currency with Germany. Sceptical commentators asked: Would these countries either default on their debts or crash out of the single currency or both. While the question of the UK Euro entry is being

\footnotetext{
${ }^{8}$ Wolfgang Münchau \& Susanne Mundschenk in "Eurozone Meltdown, Eight Scenarios how the unthinkable might happen”, Eurointelligence, Briefing Note No.1. 3 April 2009
} 
discussed amongst some economists there is no sign of a national debate about Euro entry on the horizon.

\section{The Eurozone Perspective}

If the UK wished to join that would be decided by majority vote but the rate would require unanimity amongst existing Eurozone members. Some commentators argue that the UK government's five entry tests are now adequately met and that a stable exchange rate would be beneficial in dealing with the shocks to the system following the financial crisis. ${ }^{9}$ Others argue that Britain is still better off with a flexible exchange rate and Eurozone interest rates would not necessarily be appropriate for the UK economy - the UK now has lower interest rates than the Eurozone. ${ }^{10}$ Would the UK be able to fulfil the conditions of the stability and growth pact (SGP) at least as well as the existing members? Given that the Commission forecasts that the UK's deficit will be 8.8 per cent this year and 9.6 per cent in 2010, Britain is a long way from meeting the SGP criteria on budget deficits (although its overall debt/GDP ratio remains a long way below other Eurozone members such as Belgium and Italy). Nonetheless, these are all questions which merit calm and rational debate.

In its assessment of the first 10 years of experience of the Euro ${ }^{11}$, the European Commission has claimed a success. The European Central Bank successfully brought down interest rates and anchored inflation within the Eurozone to an average of just over $2 \%$. In the absence of exchange rate risks and transaction costs, trade and investment within the Eurozone grew substantially. The conditions of the stability and growth pact (SGP) brought an impressive improvement in fiscal discipline with an overall budget deficit of only $0.6 \%$ of GDP in 2007. Externally, the Euro became increasingly important

\footnotetext{
${ }^{9}$ See, for example, Willem Buiter’s 'The Overwhelming Economic Case for the United Kingdom Adopting the Euro' in 10 years of the Euro: New Perspectives for Britain, 2009.

${ }^{10}$ See, for example, Martin Wolff's 'Eurozone Membership is still no answer for the UK', Financial Times, 18 November, 2008

${ }^{11}$ EMU@10, the European Commission, 7 May, 2008
} 
as a world currency in trade and financial services despite being constantly written off. ${ }^{12}$ It is now the second largest global reserve currency after the Dollar. The Eurozone would only decide in favour of a potential UK entry if the UK fulfilled the criteria for joining.

\section{Conclusions}

There are many obstacles that still stand in the way of British membership of European Monetary Union. And before any serious debates on the possibility of joining are even entered into, many other factors need to be considered. First, this crisis is the first real test for the Euro, and how it reacts and deals with the worsening economic picture will be seen by many as a test of its credibility.

Although membership of the Euro has eliminated the possibility of currency crises for countries such as Ireland and Spain, it does not mean that they are completely immune to shocks resulting from the global crisis. External threats could still harm their economies and that is why the events which unfold over the next few months will provide a real test for the currency and the Eurozone as a whole.

Other obstacles to British membership are based on Britain's very nature and relationship with the EU itself. The Government's 'five economic tests ${ }^{13}$ would have to be re-examined and each would have to be met before membership is even properly considered. However, even if these tests were met, the rest of Europe would then have to accept Britain's bid to join. Following that, Britain would then have to undergo a transitional period of membership of the single currency exchange rate mechanism before qualifying for full membership, which would take some years anyway.

\footnotetext{
12 See, Martin Feldstein, “Will the Euro Survive the Current Crisis?” in Project-syndicate November 2008 Martin Feldstein "EMU and International Conflict” in Foreign Affairs, November/December 1997 Martin Feldstein, "Reflections on Americans' views of the euro ex ante” in VOXEU 26 January 2009

${ }^{13}$ UK Membership of the Single Currency, An assessment of the five economic tests, HM Treasury, 9 June 2003
} 
There is currently a limited debate on the Euro issue within Britain, with it tending to get left to bashing at the hands of the tabloid press and Eurosceptics. This means that the vast majority of the British public are unenthusiastic about the project. Study after study has revealed that if a referendum on membership were to be held, it would be easily lost. In addition, the 'Europe/euro debate' is not a vote-winner in Britain and it is an issue that is likely to lead to further splits within political parties. The next general election must be called by the spring of 2010 .

Finally, it is important to note that even if the idea had crossed the minds of ministers over the past few months, aside from Lord Mandelson, no other politician has gone public in putting forward a positive case for Europe which will be essential to lay the groundwork for a Euro entry scenario. If there isn't a sizeable group of politicians in the UK that make that case there is little chance of Euro membership any time in the near future. ${ }^{14}$

William Hague, the Shadow Foreign Secretary, wrote in a New Year's Day newspaper article that the Conservatives -- if returned to power -- would never take Britain into the Euro. The latest fall in sterling, according to Hague, is not a good reason to give it up: "The idea of abandoning your currency when it has lost a lot of its value is a pretty stupid one -rather like thinking that if you have let your house run down in value until it is the same as a smaller one next door, it is a good time to swap." ${ }^{15}$

A BBC Daily Politics poll ${ }^{16}$ asked whether the current economic crisis has made people more likely to join the Euro, only 31\% agreed with 64\% disagreeing. On the question of whether Britain benefits overall from membership of the European Union in terms of jobs and trade only $44 \%$ agreed with 51\% disagreeing. Prominent French and German politicians do not think that the UK will join the Euro anytime soon. ${ }^{17}$

\footnotetext{
${ }^{14}$ www.bbc.co.uk, Mandelson rejects euro talk claim, 3 December 2008

${ }^{15}$ Tories will never take Britain into euro, Daily Mail 1 January 2009

${ }^{16}$ BBC Daily Politics: Brits want to leave EU, 18 March 2009

${ }^{17}$ David Marsh, The Euro: The Politics of the New Global Currency, Yale University Press, 2009
} 
In the UK, discussion about the merits of UK membership of the Euro has been on the table since the start of the current crisis and has highlighted the change in circumstances facing the UK economy and sterling since 2003 when the UK Government decided that the conditions laid down in its five tests were not sufficiently met. Among the questions now being asked are whether the current Sterling/Euro rate would be the right one on which to enter and whether entry would be a desirable shelter from a sterling crisis.

Although Euro membership is clearly not on the UK political agenda and has been ruled out by the Conservative Party, their reluctance to engage with the issue along with Gordon Brown's government now need not, indeed should not, preclude a proper assessment of what is in the UK's interest over the longer term given the current economic situation and the prospects for the future European and global economy. 